\title{
Somatic embryogenesis and plant regeneration of Lilium ledebourii (Baker) Boiss., an endangered species
}

\author{
Mehdi Bakhshaie • Mesbah Babalar • \\ Masoud Mirmasoumi · Ahmad Khalighi
}

Received: 16 June 2009/ Accepted: 28 February 2010/Published online: 24 March 2010

(c) The Author(s) 2010. This article is published with open access at Springerlink.com

\begin{abstract}
A somatic embryogenesis (SE) protocol was established for the regeneration of Lilium ledebourii (Baker) Boiss. whole plants using new vegetative bulblet microscales and transverse thin cell layers (tTCLs) of young bulblet roots as the explant sources. Bulblets were induced from bulb scale explants cultured for at least 3 months in the dark on Murashige and Skoog (MS) medium containing 3\% sucrose, $0.8 \%$ agar, and different concentrations of $\alpha$-naphthaleneacetic acid (NAA), 6-benzyladenine (BA), and thidiazuron. Embryo-like structures were obtained from tTCL explants of 3-month-old bulblets (excised from bulb scale explants) following culture on solid MS medium containing 3\% sucrose and various concentrations of NAA and BA for 3 months in the dark. Both the explant source and the type of plant growth regulators affected the differentiation of somatic embryos. The highest percentage $(65.55 \%)$ of embryogenesis was obtained from bulblet microscale tTCLs cultured on solid MS medium containing $0.54 \mu \mathrm{M}$ NAA and $0.44 \mu \mathrm{M}$ BA. Plants with normal shoots and roots were obtained following a 3-month culture of embryos on growth regulatorfree MS medium at $25 \pm 1^{\circ} \mathrm{C}$ under a $16 / 8$-h light/dark photoperiod (light intensity $40 \mu \mathrm{mol} \mathrm{m} \mathrm{m}^{-2} \mathrm{~s}^{-1}$, cool-white fluorescent light). The plants were successfully acclimatized in the growth chamber.
\end{abstract}

M. Bakhshaie $(\square) \cdot$ M. Babalar · A. Khalighi Department of Horticultural Sciences, Faculty of Agriculture, University of Tehran, 31587-11167 Karaj, Iran e-mail: mbakhshaie@ut.ac.ir

M. Mirmasoumi

Department of Plant Physiology, College of Sciences,

University of Tehran, Tehran, Iran
Keywords Bulblets - Endangered - Lilium ledebourii . Plant regeneration - Somatic embryogenesis .

Thin cell layer

$\begin{array}{ll}\text { Abbreviations } \\ \text { BA } & \text { 6-Benzyladenine } \\ \text { ELS } & \text { Embryo-like structures } \\ \text { MS } & \text { Murashige and Skoog's medium } \\ \text { NAA } & \alpha \text {-Naphthaleneacetic acid } \\ \text { PGRs } & \text { Plant growth regulators } \\ \text { SE } & \text { Somatic embryogenesis } \\ \text { TDZ } & \text { Thidiazuron or } N \text {-phenyl-N0-1,2,3-thiadiazol-5- } \\ & \text { ylurea } \\ \text { tTCL(s) } & \text { Transverse thin cell layer(s) }\end{array}$

\section{Introduction}

Lilium ledebourii (Baker) Boiss. (Family Liliaceae), called 'Susan-e-chelcheragh' in Persian, is the only endangered species of the Lilium genus found in Iran. It has a great potential as an ornamental plant due to its large and attractive white flowers that are the equal to those of commercial lilies in terms of beauty (Wendelbo 1977). Four to ten flowers commonly appear on each plant, but specimens with up to 15 flowers have been observed (Ghahreman 1997; Farsam et al. 2003). Lilium ledebourii is grown in the eastern slopes of Alburz Mountains, where is now protected on a small area of degraded beech forest around Damash village (1,700-1,900 m a.s.1.) (Wendelbo 1977; Rechinger 1989). Wild populations are currently at risk of rapid eradication because of irregular grazing and poaching (Azadi and Khosh-Khui 2007). Therefore, 
artificial propagation methods are necessary to conserve and maintain the germplasm.

There are several limitations to breeding L. ledebourii, such as the production of only a few seeds and restricted conventional vegetative propagation. One approach to overcoming these limitations is somatic embryogenesis (SE), which is one of the fastest methods for micropropagating whole plants. As such, SE is a highly valued plant culture technique (Fay 1992; Stanilova et al. 1994; Karami et al. 2008). The main advantage of SE compared to the other regeneration methods, such as organogenesis, is that it produces a functional meristem with a vascular system and a root/shoot axis in a single step (Bassuner et al. 2007). In contrast, shoot organogenesis requires additional manipulations, as adventitious roots have to be formed subsequent to shoot induction. Additional advantages of SE are the potential for the cryopreservation of embryos, formation of a very large number of propagules per explants, genetic transformation, and direct transfer of plants for field cultivation through the production of artificial seeds.

Somatic embryogenesis has been induced from different explants of L. longiflorum and lily hybrids (Haensch 1996; Tribulato et al. 1997; Nhut et al. 2002, 2006; Ho et al. 2006). In a number of different genotypes of bulbous ornamental crops, SE has also been reported from bulb scales as explants (e.g., L. longiflorum; ArzateFernandez et al. 1997; Fritillaria imperialis; Mohammadi-Dehcheshmeh et al. 2008), but the use of bulbs as a explant source was linked with heavy bacterial and fungal contamination. However, in terms of a perennial endangered plant species, a major disadvantage of using (pieces of) bulb scales as explant source is the destruction of the source plant. The lack of an efficient protocol for traditional asexual propagation of lily has prompted extensive studies on using the thin cell layer (TCL) method as both a tool and a solution to the use of bulb scales (Nhut et al. 2001a). TCLs have been excised from different plant organs and successfully used as explants for SE and plant regeneration processes in L. longiflorum (Van Le et al. 1999; Nhut et al. 2001a, b, 2002).

Here, we report our study on the use of bulblet transverse (t)TCLs of L. ledebourii (excised from in vitro bulb scales) as an explant source for SE and plant regeneration processes. An additional objective was to study the effects of different concentrations of growth regulators and different organ sources of TCLs derived from bulblet microscales and young bulblet roots on the formation of L. ledebourii embryogenic callus and somatic embryos. The results reported here contribute valuable information which can be used in conservation and breeding programs of L. ledebourii.

\section{Materials and methods}

Plant material and disinfection

Fresh bulbs of L. ledebourii were collected from the Damash mountain region located in Gilan province, northern Iran, in late March 2008. The bulbs were first washed under running tap water for approximately $2 \mathrm{~h}$ following removal of the roots and outer dry scales, and then the clean inner scales were excised, surface sterilized [first in $70 \%(\mathrm{v} / \mathrm{v})$ ethanol for $2 \mathrm{~min}$, then in $3 \%(\mathrm{v} / \mathrm{v})$ sodium hypochlorite solution plus 2-3 drops of Tween 20 for $30 \mathrm{~min}$ ], rinsed three times in sterile distilled water, and finally shacked for $5 \mathrm{~min}$ to wash out the sterilization agents.

Bulblet regeneration from bulb scale explants

Each section of the bulb scale $(7 \times 7 \mathrm{~mm})$, with the dorsal side in contact with the medium, was placed in a test tube $(25 \times 150 \mathrm{~mm})$ containing $20 \mathrm{ml}$ of solid MS (Murashige and Skoog 1962) medium supplemented with various growth regulators at different concentrations: (1) $\alpha$-naphthaleneacetic acid (NAA) at $0.0,0.54$, or $2.69 \mu \mathrm{M}$; (2) 6-benzyladenine (BA) at $0.0,0.44$, or $2.22 \mu \mathrm{M}$; (3) thidiazuron (TDZ) at $0.0,0.45$, or $2.27 \mu \mathrm{M}$. The MS basal medium contained MS mineral salts, 3\% (w/v) sucrose, $0.8 \%$ (w/v) agar (Merck, Whitehouse Station, NJ), $2 \mathrm{mg} \mathrm{l}^{-1}$ glycine, $100 \mathrm{mg} \mathrm{l}^{-1}$ myo-inositol, $0.5 \mathrm{mg} \mathrm{l}^{-1}$ nicotinic acid, $0.5 \mathrm{mg} \mathrm{l}^{-1}$ pyridoxine $\mathrm{HCl}$, and $0.1 \mathrm{mg} \mathrm{l}^{-1}$ thiamine $\mathrm{HCl}$. The medium was adjusted to $\mathrm{pH} 5.7$ with $0.1 \mathrm{~N} \mathrm{NaOH}$ or $\mathrm{HCl}$ and autoclaved at $121^{\circ} \mathrm{C}$ and $120 \mathrm{kPa}$ for $15 \mathrm{~min}$. The test tubes were capped with two layers of aluminum foil and cultured for 3 months at $25 \pm 1^{\circ} \mathrm{C}$ in the dark in a growth chamber. After 3 months, the morphological characters of bulblets that had grown in test tubes were recorded (Table 1).

Induction of embryo-like structures from tTLC explants

Three-month-old bulblets (excised from bulb scale explants) were used as an explant source for these experiments. In order to induce embryo-like structures (ELS), we excised and cultured different types of tTCLs (bulblet microscales and young bulblet roots, $1.0 \mathrm{~mm}$ in thickness) in petri dishes $(90 \times 20 \mathrm{~mm})$ containing $30 \mathrm{ml}$ of solid MS medium $(0.8 \%$ agar) with $3 \%$ sucrose and supplemented with $0.54 \mu \mathrm{M}$ NAA and $0.0,0.44$, or $2.22 \mu \mathrm{M}$ BA. These cultures were incubated under the same conditions as for the bulb scale culture. To maintain the ELS type, ELS masses were cut into small segments and subcultured on the same medium at 4-week intervals. 
Table 1 Regeneration of bulblets from bulb scale explants of Lilium ledebourii after 90 days of culture

\begin{tabular}{|c|c|c|c|c|c|c|}
\hline \multicolumn{3}{|c|}{ Plant growth regulators $(\mu \mathrm{M})$} & \multirow{2}{*}{$\begin{array}{l}\text { Percentage of bulblets } \\
\text { regenerated from bulb } \\
\text { scale explants }\end{array}$} & \multirow{2}{*}{$\begin{array}{l}\text { Number of } \\
\text { bulblets/explant }\end{array}$} & \multirow{2}{*}{$\begin{array}{l}\text { Fresh weight } \\
\text { of bulblet }(\mathrm{g})\end{array}$} & \multirow{2}{*}{$\begin{array}{l}\text { Number of } \\
\text { roots/bulblet }\end{array}$} \\
\hline NAA & $\mathrm{BA}$ & TDZ & & & & \\
\hline 0.0 & 0.0 & 0.0 & $24.00 \mathrm{~d}$ & $1.33 \mathrm{~d}$ & $0.36 \mathrm{a}$ & $3.66 \mathrm{a}$ \\
\hline 0.54 & 0.0 & 0.45 & $96.00 \mathrm{~b}$ & $1.66 \mathrm{c}$ & $0.28 \mathrm{~b}$ & $0.00 \mathrm{c}$ \\
\hline 2.69 & 0.0 & 2.27 & $88.00 \mathrm{c}$ & $1.83 \mathrm{~b}, \mathrm{c}$ & $0.21 \mathrm{e}$ & $0.00 \mathrm{c}$ \\
\hline 0.54 & 0.44 & 0.0 & $100.00 \mathrm{a}$ & $2.37 \mathrm{a}$ & $0.25 \mathrm{c}$ & $3.63 \mathrm{a}$ \\
\hline 2.69 & 2.22 & 0.0 & $100.00 \mathrm{a}$ & $1.93 \mathrm{~b}$ & $0.24 \mathrm{~d}$ & $3.17 \mathrm{~b}$ \\
\hline
\end{tabular}

NAA, $\alpha$-Naphthaleneacetic acid; BA, 6-benzyladenine; TDZ, thidiazuron

Values followed by different lower case letters within a column indicate significant differences at $P \leq 0.05$ by Duncan's multiple range test

Regeneration of plantlets from somatic embryos

ELS were cultured on hormone-free MS medium for plant regeneration. The culture conditions were $25 \pm 1^{\circ} \mathrm{C}$ and a 16/8-h light/dark photoperiod with light provided by coolwhite fluorescent lights at an intensity of $40 \mu \mathrm{mol} \mathrm{m} \mathrm{m}^{-2} \mathrm{~s}^{-1}$. The germinated plantlets were transferred to the regeneration medium in tissue culture jars to allow the bulblets to further develop. After the scaly leaves had wilted (8-12 weeks), the bulblets were ready for vernalization (8 weeks at $5^{\circ} \mathrm{C}$ ).

\section{Acclimatization of regenerated plantlets}

Following vernalization, 3-month-old, healthy regenerated plantlets with well-developed roots were removed from the culture medium. The roots were carefully washed under running tap water to remove adhering culture media, and the plants were transferred to a sterile peat:perlite $(1: 1, \mathrm{v} / \mathrm{v})$ substrate in plastic pots $(8 \times 7 \mathrm{~cm})$ for acclimatization. All plants were covered with transparent plastic cups to provide a high relative humidity. The plants were kept in the growth chamber under controlled conditions for 2 weeks and then transferred to conditions of a natural light/dark cycle of sunlight without temperature control in the laboratory for another 2 weeks. The cover was gradually removed during this period of time.

\section{Statistical analysis}

At the stage of bulblet regeneration from bulb scales, one explant was cultured in a test tube. The percentage of bulblets regenerated from each scale, the number of bulblets per explant, fresh weight of the bulblet, and the number of roots per bulblet formed per explant were recorded after 90 days of culture. In order to induce ELS from tTCL explants, five explants were cultivated in a petri dish. The following data were recorded: percentage of surviving explants, percentage of embryos forming calluses, number of ELS per explant, and fresh weight of ELS. In all experiments, a completely randomized design was used with 25 replicates per treatment. All collected data were subjected to the analysis of variance, and the mean separation was performed using Duncan's multiple range tests at a significance level of $P \leq 0.05$.

\section{Results and discussion}

Effect of plant growth regulators on bulblet regeneration

After 3 months of culture, bulblets had been regenerated via direct organogenesis in all bulb scale explants cultured on all media. Explants cultured on media containing NAA and BA showed $100 \%$ bulblet regeneration (Table 1). This result is consistent with those of Azadi and Khosh-Khui (2007) who reported similar results for the L. ledebourii in winter-harvested bulbs. The highest number of bulblets (2.37) was obtained on explants cultured on medium supplemented with $0.44 \mu \mathrm{M}$ BA and $0.54 \mu \mathrm{M}$ NAA (Fig. 1a). The number of bulblets per scale increased with increasing levels of plant growth regulators (PGRs), but the presence of PGRs led to a decrease in the fresh weight of the bulblets compared to the control (Table 1).

No roots were produced by bulb scale segments of L. ledebourii cultured on medium containing 0.45 and $2.27 \mu \mathrm{M}$ TDZ (Table 1). Although TDZ has been effectively used to induce shoot regeneration in different explants of various lily species (Bacchetta et al. 2003; Han et al. 2005; LingFei et al. 2009), its use has not been reported for L. ledebourii. TDZ is also a potent PGR in in vitro morphogenesis and is considerably more effective than other cytokinins for inducing shoot regeneration (Huetteman and Preece 1993). It is a powerful inducer of adventitious shoots and somatic embryo formation in many ornamental plants (Lin et al. 1997; Mirici et al. 2005; Sanikhani et al. 2006). In our study, however, it was not as 
Fig. 1 Somatic embryogenesis and plantlet regeneration from transverse thin cell layers (tTCLs) of Lilium ledebourii (Baker) Boiss. (Liliaceae) a Regenerated bulblets without leaves from a segment of a bulb scale cultured on MS medium containing of $0.54 \mu \mathrm{M}$ NAA and $0.44 \mu \mathrm{M}$ BA for 3 months in the dark. Bar: $5 \mathrm{~mm}$.

b Friable callus obtained from tTCLs of bulblet microscales.

Bar: $1 \mathrm{~mm}$. c Globular somatic embryos. Bar: $1 \mathrm{~mm}$.

d Embryos in cotyledonary stage. Bar: $1 \mathrm{~mm}$. e Plantlets with shoots and roots formed from somatic embryos cultured on a hormone-free MS medium under a 16/8-h light/dark photoperiod. f Acclimatized plantlets after 6 weeks of cultivation in pots
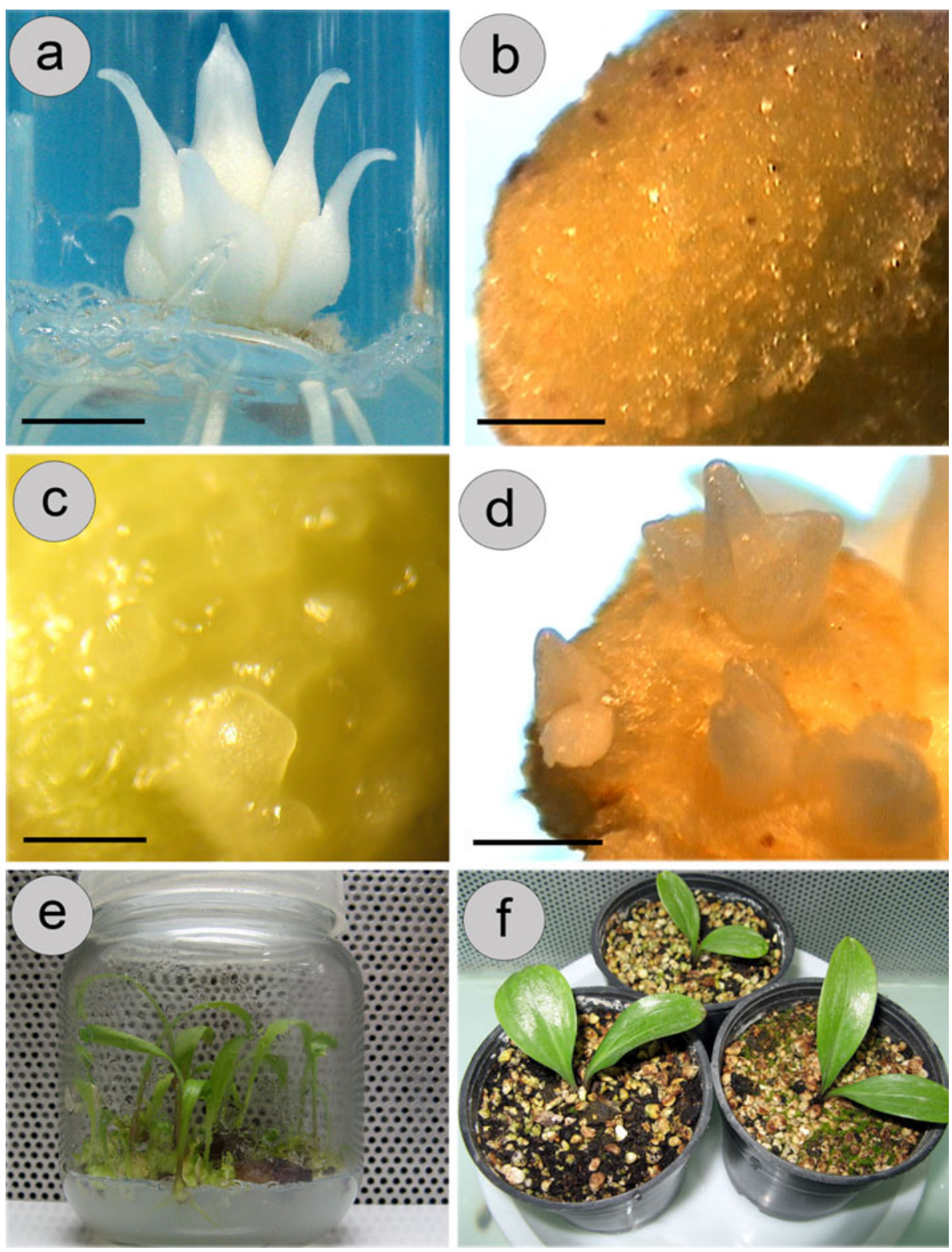

effective as BA in stimulating bulblet regeneration by L. ledebourii (Table 1). This was possibly due to the involvement of TDZ in the modulation of endogenous growth regulators, the type of tissue, genotype, and type of auxin which was combined with TDZ (Passey et al. 2003; Landi and Mezzetti 2006).

\section{Induction of SE}

Somatic embryogenesis occurred in tTCL explants of L. ledebourii cultured on MS media containing different concentrations of NAA and BA. Four weeks after the initiation of tTCL culture, the percentage of surviving explants was calculated by dividing the number of surviving explants by the number of cultured explants. The maximum survival percentage of tTCL explants $(100 \%)$ was obtained from bulblet microscales cultured on MS media containing both NAA and BA (Table 2). tTCL explants were cultured on MS media supplemented with 3\% sucrose, $0.8 \%$ agar, and various concentrations of PGRs were swollen, mainly from the cut end of the explants, and produced yellowish nodular embryogenic calluses within 4 weeks of culture in the dark (Fig. 1b). Four to 5 weeks after tTLC culture initiation, globular somatic embryos were obtained by continuous cultivation on solid MS media (Fig. 1c). The concentration of NAA and BA affected the number of somatic embryos, with the MS medium containing $0.54 \mu \mathrm{M}$ NAA and $0.44 \mu \mathrm{M}$ BA producing the highest somatic embryo induction among all media containing PGRs. No SE occurred in young bulblet root explants grown on media without cytokinins (Table 2). These results suggest that there are highly significant differences between explant 
Table 2 Effect of L. ledebourii explant type on the percentage explant survival rate, percentage of somatic embryos forming calluses, number of ELS per explant, and fresh weight of ELS masses when cultured on MS media containing NAA and BA for 3 months

\begin{tabular}{|c|c|c|c|c|c|c|}
\hline \multirow[t]{2}{*}{ Explant type } & \multicolumn{2}{|c|}{ Plant growth regulators $(\mu \mathrm{M})$} & \multirow{2}{*}{$\begin{array}{l}\text { Percentage } \\
\text { survival rate }\end{array}$} & \multirow{2}{*}{$\begin{array}{l}\text { Percentage of somatic } \\
\text { embryo forming calluses }\end{array}$} & \multirow{2}{*}{$\begin{array}{l}\text { Number of } \\
\text { ELS/explant }\end{array}$} & \multirow{2}{*}{$\begin{array}{l}\text { Fresh weight of } \\
\text { ELS masses }(\mathrm{g})\end{array}$} \\
\hline & NAA & BA & & & & \\
\hline \multirow[t]{3}{*}{ Root } & 0.54 & 0.0 & $0.00 \mathrm{e}$ & $0.00 \mathrm{e}$ & $0.00 \mathrm{e}$ & $0.00 \mathrm{f}$ \\
\hline & 0.54 & 0.44 & $59.57 \mathrm{c}$ & $30.14 \mathrm{~d}$ & $3.84 \mathrm{a}$ & $0.85 \mathrm{~d}$ \\
\hline & 0.54 & 2.22 & $56.49 \mathrm{~d}$ & $28.75 \mathrm{~d}$ & $2.71 \mathrm{c}$ & $0.74 \mathrm{e}$ \\
\hline \multirow[t]{3}{*}{ Scale } & 0.54 & 0.0 & $65.39 \mathrm{~b}$ & $44.61 \mathrm{c}$ & $1.82 \mathrm{~d}$ & $1.30 \mathrm{c}$ \\
\hline & 0.54 & 0.44 & $100.00 \mathrm{a}$ & $65.55 \mathrm{a}$ & $3.22 \mathrm{~b}$ & $1.86 \mathrm{a}$ \\
\hline & 0.54 & 2.22 & $100.00 \mathrm{a}$ & $58.20 \mathrm{~b}$ & $3.69 \mathrm{a}$ & $1.46 \mathrm{~b}$ \\
\hline
\end{tabular}

ELS, Embryo-like structures

Values followed by different letters within a column indicate significant differences at $P \leq 0.05$ by Duncan's multiple range test

types when tTCLs were cultured on the medium with the different NAA and BA combinations. Explants were taken from the bulblet microscales generally produced more calluses with somatic embryos than young bulblet root explants (Table 2). The highest ELS per tTCL explant (3.84) was obtained from a tTCL from a young bulblet root cultured on MS media containing $0.54 \mu \mathrm{M}$ NAA and $0.44 \mu \mathrm{M}$ BA. The embryo number per tTCL of bulblet microscale explants was nearly equal to that per tTCL of young bulblet root explants (Table 2). Subculturing of ELS under the same conditions as for the callus culture gave rise to new ELS on MS medium and, subsequently, the development of dicotyledonous embryos (Fig. 1d). During the experiment, callus fresh weight increased with increasing duration of the culture period. The fresh weight of the ELS masses was higher on medium with $0.54 \mu \mathrm{M}$ NAA and $0.44 \mu \mathrm{M}$ BA after 3 months of culture compared to that on media with other PGR combinations (Table 2).

During the last two decades, a number of protocols have been developed for the establishment of SE and callus cultures of $L$. longiflorum and a number of lily hybrids (Haensch 1996; Tribulato et al. 1997; Nhut et al. 2002, 2006; Ho et al. 2006). To date, there has been no report describing this regeneration process from tTCL explants of L. ledebourii. Haensch (1996) obtained whole plants from bulb scales in different genotypes of Lilium hybrids when explants were cultured on MS medium. Tribulato et al. (1997) reported embryogenic cell suspensions and plant regeneration of $L$. longiflorum 'Snow Queen' from friable callus when explants were cultured in liquid medium containing $2 \mu \mathrm{M}$ dicamba. Nhut et al. (2002) reported that MS medium containing 5.4 $\mu \mathrm{M}$ NAA and $1.1 \mu \mathrm{M}$ TDZ induced yellow friable calluses derived from $L$. longiflorum tTCL explants but that some of the pseudo-bulblet explants failed to generate somatic embryos when $0.5-$ to $0.7-\mathrm{mm}$ thick tTCLs were used as explants. These researchers found $0.8-$ to $1.0-\mathrm{mm}$ thick explants were the best source material for obtaining the maximum number of ELS. In contrast, we found that the addition of BA and NAA to MS medium resulted in the production of yellowish nodular embryogenic calluses. In Lilium species, the requirement for BA or TDZ to induce somatic embryos may depend on the explant source, genotype, PGRs, and culture conditions. Ho et al. (2006) stated that $5.3 \mu \mathrm{M}$ NAA induced green embryogenic callus from roots near the base of bulblets of Lilium $\times$ formolongi and that subsequent embryo development occurred in flask culture and bioreactor culture. We found that the lower concentration of NAA induced embryogenic callus and that somatic embryos formed thereafter when grown on growth PGR-free medium in the dark. Nhut et al. (2006) reported that liquid culture was the better culture condition, compared to solid media, for inducing and enhancing the quality and quantity of SE from tTCL (explant thickness $0.8-1.0 \mathrm{~mm}$ ) of pseudobulblets of L. longiflorum 'Easter Lily'. The germination and subsequent development of somatic embryos into plantlets occurred on hormone-free half-strength MS medium. In contrast, our results showed that embryogenic callus could not be induced from tTCLs of bulblet microscales cultured in the dark on MS medium containing NAA and TDZ in L. ledebourii (data not shown), while embryos showing a bipolar structure were developed in the presence of NAA or in combination with BA. Similarly, the combination of an auxin and BA has been used to initiate somatic embryos in other rhizomatous and bulbous ornamental crops, such as Alstroemeria (Kim et al. 2006), Iris (Shibli and Ajlouni 2000), Narcissus (Selles et al. 1999; Malik 2008), and Tulipa (Ptak and Bach 2007).

\section{Somatic embryo germination and plant acclimatization}

Embryo-like structures with normal shoots and roots germinated 3 months after being cultured on hormone-free MS medium (Fig. 1e). Four to 5 months later, after the scaly leaves had wilted, the plantlets were removed from the culture vessels and the bulblets vernalized. Similar to 
results reported for other species (Nhut et al. 2006; Ho et al. 2006), the highest germination rate $(83 \%)$ of transforming somatic embryos into plants was observed in L. ledebourii. More than $75 \%$ of rooted plantlets were successfully adapted to ex vitro conditions (Fig. 1f). The plantlets were very uniform and continued to grow, showing the development of new leaves. Thus, SE in L. ledebourii is an efficient procedure for propagation.

In conclusion, our study is the first to report on successful plant regeneration via SE from tTCLs of $L$. $l e$ debourii. The TCL system enables not only rapid clonal propagation but also provides an excellent source of material for genetic manipulation, thereby enabling the development of new varieties. As such, TCL cultures would also appear to be suitable as a valuable target tissue for Agrobacterium transformation. In some Lilium species and cultivars, genetic transformations have already been performed successfully (Watad et al. 1998; Hoshi et al. 2004; Mori et al. 2005; Kim et al. 2007). The procedure described here is efficient and can be applied in programs aimed at conserving this valuable genetic resource.

Open Access This article is distributed under the terms of the Creative Commons Attribution Noncommercial License which permits any noncommercial use, distribution, and reproduction in any medium, provided the original author(s) and source are credited.

\section{References}

Arzate-Fernandez AM, Nakazaki T, Okumoto Y, Tanasika T (1997) Efficient callus induction and plant regeneration from filaments with anther in lily (Lilium longiforum Thunb). Plant Cell Rep 16:836-840. doi:10.1007/s002990050330

Azadi P, Khosh-Khui M (2007) Micropropagation of Lilium ledebourii (Baker) Boiss as affected by plant growth regulator, sucrose concentration, harvesting season and cold treatments. Electron $\mathrm{J}$ Biotechnol 10:582-591. doi:10.2225/vol10-issue4-fulltext-7

Bacchetta L, Remotti PC, Bernardini C, Saccardo F (2003) Adventitious shoot regeneration from leaf explants and stem nodes of Lilium. Plant Cell Tissue Organ Cult 74:37-44

Bassuner BM, Lam R, Lukowitz W, Yeung EC (2007) Auxin and root initiation in somatic embryos of Arabidopsis. Plant Cell Rep 26:1-11. doi:10.1007/s00299-006-0207-5

Farsam H, Amanlou M, Amin G, Nezamivand-Chegini G, SalehiSurmaghi M, Shafiee A (2003) Anatomical and phytochemical study of Lilium ledebourii (Baker) Boiss., a rare endemic species in Iran. DARU 11:164-170

Fay MF (1992) Conservation of rare and endangered plants using in vitro methods. In Vitro Cell Dev Biol Plant 28:1-4. doi:10.1007/ BF02632183

Ghahreman A (1997) Flora of Iran, vol 16, no. 1944, code 137, 001, 001. Research Institute of Forests and Rangelands, Tehran

Haensch KT (1996) Plant regeneration through somatic embryogenesis in different genotypes of Lilium hybrids. Gartenbauw 61:214-218

Han BH, Yae BW, Hee JY, Peak KY (2005) Improvement of in vitro micropropagation of Lilium oriental hybrid 'Casablanca' by the formation of shoots with abnormally swollen basal plates. Sci Hortic 103:351-359
Ho CW, Jian WT, Lai HC (2006) Plant regeneration via somatic embryogenesis from suspension cell cultures of Lilium $\times$ formolongi Hort. using a bioreactor system. In Vitro Cell Dev Biol Plant 42:240-246. doi:10.1079/IVP2006756

Hoshi Y, Kondo M, Mori S, Adachi Y, Nakano M, Kobayashi H (2004) Production of transgenic lily plants by Agrobacteriummediated transformation. Plant Cell Rep 22:359-364. doi: 10.1007/s00299-003-0700-z

Huetteman CA, Preece JE (1993) Thidiazuron: a potent cytokinin for woody plant tissue culture. Plant Cell Tissue Organ Cult 33:105119. doi:10.1007/BF01983223

Karami O, Deljou A, Karimi Kordestani G (2008) Secondary somatic embryogenesis of carnation (Dianthus caryophyllus L.). Plant Cell Tissue Organ Cult 92:273-280. doi:10.1007/s11240-0079332-2

Kim JB, Raemakers CJJM, Jacobsen E, Visser RGF (2006) Efficient somatic embryogenesis in Alstroemeria. Plant Cell Tissue Organ Cult 86:233-238. doi:10.1007/s11240-006-9110-6

Kim SS, Shin DI, Park HS (2007) Transient b-glucuronidase expression in lily (Lilium longflorum L.) pollen via woundingassisted Agrobacterium-mediated transformation. Biotechnol Lett 29:965-969

Landi L, Mezzetti B (2006) TDZ, auxin and genotype effects on leaf organogenesis in Fragaria. Plant Cell Rep 25:281-288. doi: 10.1007/s00299-005-0066-5

Lin HS, De Jeu MJ, Jacobsen E (1997) Direct shoot regeneration from excised leaf explants of in vitro grown seedlings of Alstroemeria L. Plant Cell Rep 16:770-774. doi:10.1007/ s002990050317

LingFei X, FengWang M, Dong L (2009) Plant regeneration from in vitro cultured leaves of Lanzhou lily (Lilium davidii var. unicolor). Sci Hortic 119:458-461. doi:10.1016/j.scienta.2008. 08.026

Malik M (2008) Comparison of different liquid/solid culture systems in the production of somatic embryos from Narcissus L. ovary explants. Plant Cell Tissue Organ Cult 94:337-345. doi:10.1007/ s11240-008-9415-8

Mirici S, Parmaksiz I, Ozcan S, Sancak C, Uranbey S, Sarihan EO, Gumuscu A, Gurbuz B, Arslan N (2005) Efficient in vitro bulblet regeneration from immature embryos of endangered Sternbergia fischeriana. Plant Cell Tissue Organ Cult 80:239-246. doi: 10.1007/s11240-004-3016-y

Mohammadi-Dehcheshmeh M, Khalighi A, Naderi R, Sardari M, Ebrahimie E (2008) Petal: a reliable explant for direct bulblet regeneration of endangered wild populations of Fritillaria imperialis L. Acta Physiol Plant 30:395-399. doi:10.1007/ s11738-007-0126-2

Mori S, Adachi Y, Horimoto S, Suzuki S, Nakano M (2005) Callus formation and plant regeneration in various Lilium species and cultivars. In Vitro Cell Dev Biol Plant 41:783-788. doi:10.1079/ IVP2005707

Murashige T, Skoog F (1962) A revised medium for rapid growth and bioassays with tobacco tissue cultures. Physiol Plant 15:473497. doi:10.1111/j.1399-3054.1962.tb08052.x

Nhut DT, Le BV, Da Silva JAT, Aswath CR (2001a) Thin cell layer culture system in Lilium: regeneration and transformation perspectives. In Vitro Cell Dev Biol Plant 37:516-523. doi: 10.1007/s11627-001-0090-2

Nhut DT, Le BV, Van KTT (2001b) Manipulation of the morphogenetic pathways of Lilium longiflorum transverse thin cell layer explants by auxin and cytokinin. In Vitro Cell Dev Biol Plant 37:44-49. doi:10.1007/s11627-001-0009-y

Nhut DT, Bui VL, Minh NT, Teixeira da Silva JA, Fukai S, Tanaka M, Tran Thanh Van K (2002) Somatic embryogenesis through pseudo-bulblet transverse thin cell layer of Lilium longiflorum. Plant Growth Reg 37:193-198 
Nhut DT, Hanh NTM, Tuan PQ, Nquyet LTM, Tram NTH, Chinh NC, Nguyen NH, Vinh DN (2006) Liquid culture as a positive condition to induce and enhance quality and quantity of somatic embryogenesis of Lilium longiflorum. Sci Hortic 110:93-97. doi: 10.1016/j.scienta.2006.05.015

Passey AJ, Barrett KJ, James DJ (2003) Adventitious shoot regeneration from seven commercial strawberry cultivars (Fragaria $\times$ ananassa Duch.) using a range of explant types. Plant Cell Rep 21:397-401

Ptak A, Bach A (2007) Somatic embryogenesis in tulip (Tulipa gesneriana L.) flower stem cultures. In Vitro Cell Dev Biol Plant 43:35-39. doi:10.1007/s11627-006-9004-7

Rechinger KH (1989) Flora Iranica, no. 165, Liliaceae. Akademische Druck-u, Verlgsantalt, Graz

Sanikhani M, Frello S, Serek M (2006) TDZ induces shoot regeneration in various Kalanchoë blossfeldiana Poelln. cultivars in the absence of auxin. Plant Cell Tissue Organ Cult 85:7582. doi:10.1007/s11240-005-9050-6

Selles M, Viladomat F, Bastida J, Codina C (1999) Callus induction, somatic embryogenesis and organogenesis in Narcissus confusus: correlation between the state of differentiation and the content of galanthamine and related alkaloids. Plant Cell Rep 18:646-651. doi:10.1007/s002990050636

Shibli RA, Ajlouni MM (2000) Somatic embryogenesis in the endemic black iris. Plant Cell Tissue Organ Cult 61:15-21

Stanilova MI, Ilcheva VP, Zagorska NA (1994) Morphogenetic potential and in vitro micropropagation of endangered plant species Leucojum aestivum L. and Lilium rhodopaeum Delip. Plant Cell Rep 13:451-453. doi:10.1007/BF00231965

Tribulato A, Remotti PC, Loffler HJM, Van Tuyl JM (1997) Somatic embryogenesis and plant regeneration in Lilium longiflorum Thunb. Plant Cell Rep 17:113-118. doi:10.1007/s002990050362

Van Le B, Nhut DT, Van KTT (1999) Plant production via shoot regeneration from thin cell layer pseudo-bulblets explants of Lilium longiflorum in vitro. C R Acad Sci 322:303-310. doi: 10.1016/S0764-4469(99)80066-3

Watad AA, Yun DJ, Matsumoto T, Niu X, Wu Y, Kononowicz AK, Bressan RA, Hasegawa PM (1998) Microprojectile bombardment-mediated transformation of Lilium longiflorum. Plant Cell Rep 17:262-267. doi:10.1007/s002990050389

Wendelbo P (1977) Tulips and irises of Iran and their relatives. Botanical Institute of Iran, Tehran 